\title{
AUTUMN SCHOOL OF THE UNIVERSITY OF TARTU'S DEPARTMENT OF ART HISTORY: ART AND BEAUTY
}

The traditional Autumn School of the University of Tartu's Department of Art History was conducted on 16 and 17 October 2014 in cooperation with the Tartu University Art Museum and Tartu Art Museum, under the provocatively grand name of "Art and Beauty".

On the one hand, the objective of the undertaking was to introduce the development and modification of the concept of beauty in the history of aesthetics and art; and on the other hand, to examine the problematic relationship that contemporary art and theory has with beauty. Thus, the first day of the Autumn School was devoted to the classical traditions of beauty and their peak at the turn of the $19^{\text {th }}$ century, when the University of Tartu was reopened, its ensemble of buildings built and the art museum established. The topic of ideal masculine beauty in the classical art tradition was covered as a separate topic. In addition to the presentations, the interest of the Enlightenment in the human body and antique sculpture was associated with the art project created specially for the Autumn School by Jaanus Samma, a respected and well-known young Estonian artist. He made an "incursion" into the environment of the first day at the Autumn School - into the exposition at the University of Tartu Art Museum - and viewed the period of re-discovering of the antique era from his unique artist's perspective.

DOI: http://dx.doi.org/10.12697/BJAH.2014.8.06

Translation by Juta Ristsoo. 
On the second day of the Autumn School, at the Tartu Art Museum, an analysis of the meaning(s) of art in the 20th century and thereafter, today's art, exhibition and media landscape was conducted with the participation of artists, curators and art critics.

The first day of the Autumn School was opened by Juhan Maiste, Professor of Art History at the University of Tartu, whose presentation called "Why Then '...Does Laocoön Not Scream in Marble'?" was an aesthetic and philosophical introduction to the topic of antique reception, reflecting on the connection between beauty and truth, based on the interpretations of Laocoön by J. J. Winckelmann, G. E. Lessing, G. Herder and J. W. Goethe.

This was followed by a thorough survey of the valorisation of Ancient Greek and Roman sculpture and its most famous examples (The Discus Thrower, Laocoön Group, Apollo Belvedere, etc.) during the Renaissance and in the $18^{\text {th }}$ century, presented by Juta Keevallik, an expert on $18^{\text {th }}$ and $19^{\text {th }}$ century art, and former faculty member at the University of Tartu and the Estonian Academy of Arts. Keevallik's instructive discussion demonstrated the influential afterlife of antique sculpture, not only in the art of the Renaissance and during the Classicist period, but also in the taste preferences of totalitarian societies, as well as in $20^{\text {th }}$-century visual arts more broadly - all the way to souvenir shops and the beauty industry.

The presentation called "Jäsche \& Morgenstern's Double Gaze at the Tartu Sky in February 1808 in the Context of Kant's Approach to Beauty"1 by Eduard Parhomenko, Lecturer in the History of Philosophy at the University of Tartu, was based on an analysis of an entry in the diary of G. B. Jäsche (1762-1842), Professor of Philosophy at the University of Tartu and a student of Kant, which describes the ecstatic view of the wintry sky in Tartu that was revealed to him and his companion Professor K. S. Morgenstern (1770-1852), who taught philology, aesthetics, literary and art history at the University of Tartu, in 1808. In his description of this sublime experience of nature shared by the Tartu professors, Parhomenko focused on beauty and the sublime and juxtaposed Jäsche's description with the end of Kant's Critique of Practical Reason where the sky is also examined along with the mutual connections between the sublime and the moral.

1 An article on the same subject, but with a slightly different emphasis is also being published by Eduard Parhomenko: Eduard Parhomenko, „Himmel als Stimmungsbogen des Denkens über Tartu im Februar 1808“, Studia Philosophica Estonica (Tartu, 2014), xx-xx, being published. 
Moonika Teemus, Keeper of the University of Tartu Library's art collection, who, in the course of writing her master's thesis ${ }^{2}$ has dealt at length with Professor K. S. Morgenstern's personal archives and manuscripts, compared the art preferences and views of the first professor of art history at the University and the founders of the University's Art Museum with those of Friedrich Schlegel the early romanticist from Jena. The presentation was based, on the one hand, on the writings by Schlegel in 1803 in the journal Europe on the paintings by the Old Masters assembled in Paris during the Napoleonic Era, and on the other hand, on Morgenstein's notes and art articles based on his trip to Paris in 1809.

In addition to the philosopher Eduard Parhomenko, an interdisciplinary note was also introduced to the art historians' event by Jaanika Anderson, the Head of the University of Tartu Art Museum and PhD candidate in classical philology, with her presentation "Belvedere Torso - Prof. Malmberg - Skeiron". In her introduction of W. Malmberg (18601921), who was the director of the Classical Archaeology Museum ${ }^{3}$ in the early $20^{\text {th }}$ century, the presenter related Malmberg's daring theory that the famous Belvedere Torso (Vatican Museums), which is most often associated with the figure of Heracles, may actually be a depiction of the Greek robber Skeiron. What makes Malmberg's logic, which garnered some international attention, interesting is its transdisciplinary approach - his cooperation with the Department of Medicine at the University of Tartu, on whose measurements he based his opinion regarding the probable postures of the missing limbs and thereby the model for the statue.

Dr Tiina-Mall Kreem from the Kadriorg Art Museum is preparing an exhibition for 2015 related to the Enlightenment era physiognomist Johann Kaspar Lavater, his impact on art and his repute in the Baltic provinces. In the Autumn School presentation, Kreem also dealt with Lavater's ideas related to the beauty and ugliness of people's facial features and the ability to identify these features.

The first day of the Autumn School was drawn to a close by artist and Academy of Arts PhD student Jaanus Samma. Jaanus Samma, who won

2 Moonika Teemus, Musée Napoléoni maaligalerii Karl Morgensterni pilgu läbi 1809. aastal : kunsti retseptsioonist Eestis 19. sajandi alguskümnendil: Master's thesis, adviser Juta Keevallik (Tartu: Tartu Ülikool, filosoofiateaduskond, Ajaloo ja arheoloogia instituut: 2010).

3 From 1919 to 1998, the University of Tartu Art Museum, which was founded by K. S. Morgenstern, was called the Classical Archaeology Museum. 


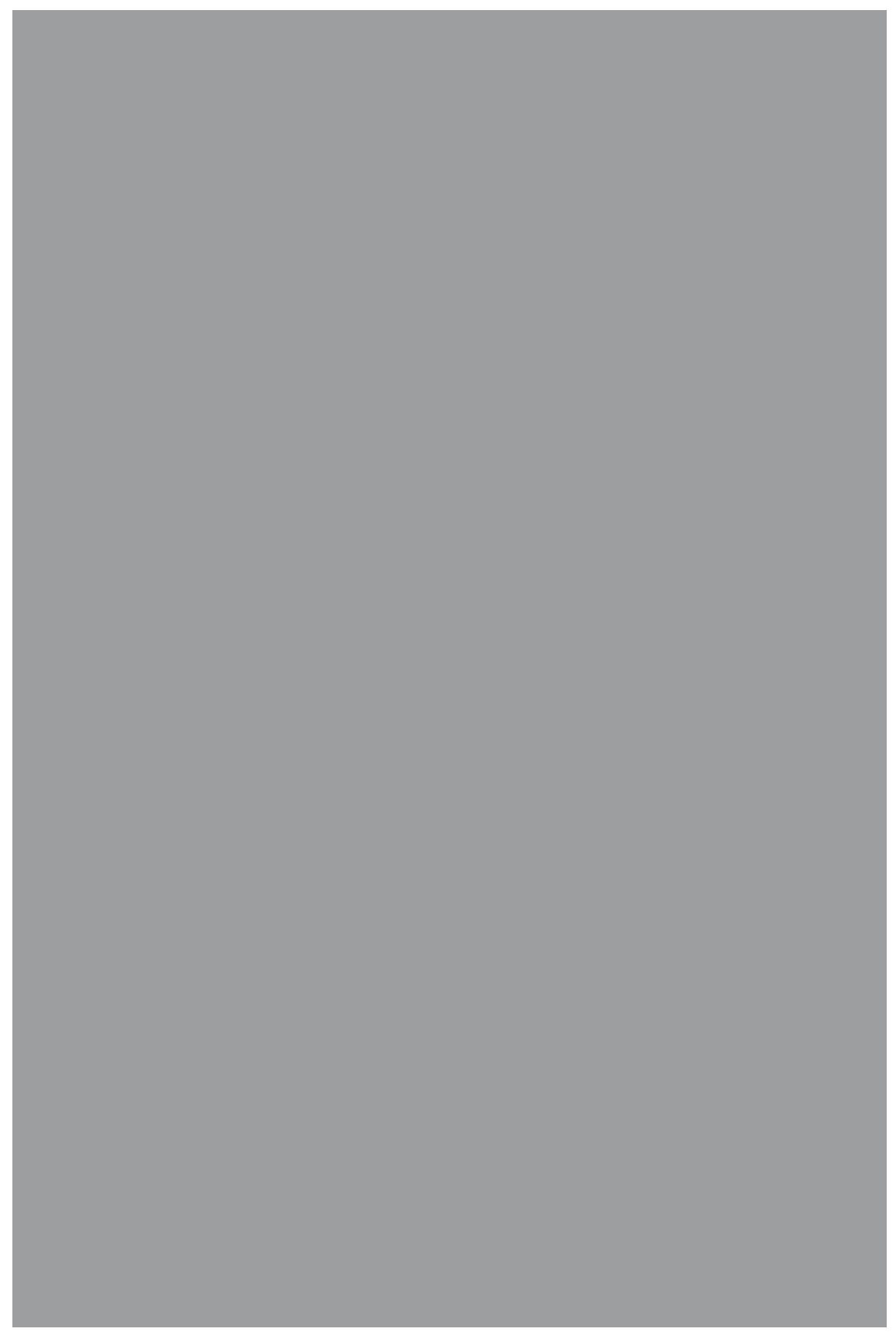

Fig. 1. Artist Jaanus Samma's light installation in the University of Tartu Art Museum. October 2014. Photo: Jaanus Samma.

Fig. 2. Artist Jaanus Samma's light installation in the University of Tartu Art Museum. October 2014. Photo: Jaanus Samma. 
the Köler Prize in 2013 and will represent Estonia at the Venice Biennale in 2015, can be characterised on the basis of his portfolio as an artist who presents "an ambivalent game involving male erotica and gay symbolism and weaves clever intrigues with his refined humour by combining the public space and sexual history with erotic desires"'4. For the Autumn School, he produced a special light installation for the permanent exposition of the plaster copies of antique statues at the University of Tartu Art Museum - fig leaves moving in the wind covered the intimate parts of the male figures - which, on the one hand, directed attention at the taboos related to physical nudity and, on the other hand, to the level of detail that permeated the examination, measurement and interpretative processes that accompanied the admiration and research of Antiquity. Samma's installation provided very interesting added value to both the Autumn School and the University of Tartu Art Museum and created an intriguing connection between the exhibition in the University's art museum and the personal position of artist today.

The second day of the Autumn School, which as a sign of the shift in time period, had moved from the University of Tartu Art Museum to the Tartu Art Museum, was opened by a presentation by Professor Emeritus Jaak Kangilaski called "Aesthetic Upheavals in the $20^{\text {th }}$ Century". His synoptic treatment of the changes that have occurred in the concepts of beauty during the $20^{\text {th }}$ century in the context of art theory and the resounding belief in the ambivalent nature of beauty (in the words of the medieval scholar St. Bonaventura: "the image of the devil is beautiful when it well represents the turpitude of the devil") was a good introduction to the others speakers of the day, who continued with more subjective approaches or focused on introducing individual schools of art.

Thus, Liisa Kaljula, a PhD student from Tallinn University and curator of the Painting Collection at the Art Museum of Estonia, presented her vision of the alteration of beauty in modernism, by illustrating the withdrawal from strictly aesthetic objects that had its start in the art of the Romanticist period with the opening of new social dimensions. With the help of many pictorial examples, Kaljula also dealt with Julia Kristev's concept of the abject and its appearance in $20^{\text {th }}$-century art.

4 Rebeka Põldsam, Jaanus Samma, 2012: http://www.cca.ee/kunstnikud/jaanus-samma (viewed on 05.11.2014). 
Tõnis Tatar, a faculty member in the Department of Art History at the University of Tartu, shared his views on the relations between beauty and art in the context of aesthetics. Through the metaphoric title "Art and Beauty: Scenes from a Marriage" he alluded in his presentation to the connection between art and beauty as a soap-opera style marriage, which has broken down a long time ago and is forcing us to choose sides. Tatar's unexpectedly elitist and aesthetic positions regarding contemporary art and the paper's "me-centred" presentation included literary allegory and sincerity, but also deliberate provocation, and provided a lot of food for thought and opportunities for discussion.

A conservative viewpoint of art - although not as a personal worldview, but as an effortless survey of America's neoconservative art policy - was also represented by Kadri Asmer, Keeper of the Tartu Art Museum's Collection of Graphic Art and Drawings. Her presentation called "The Importance and Position of Beauty in the Context of Neo-Conservatism" was based on the master's thesis entitled "Neo-Conservative Cultural Theory in the United States in 1960-1990", which she recently defended in the Department of Art History at the University of Tartu.

The presentation titled "Is Discontinuance Irreversible? What Happens to the Concept of Beauty if Art Crosses the Boundaries of Aesthetics?" by Eha Komissarov, one of Estonia's most renowned experts on contemporary art and curator at the Kumu Art Museum, created the expected polarity between the conservative and radical approaches to art, by blaming the increase of conservatism on the economic crisis and comparing the (Tartu) art scene based on traditions with Bourdieu's closed society, in which the central role is not played by the acquisition of new knowledge but by the maintenance of previously acquired skills. As a contrast, she described the sensitivity and openness and ability to change favoured by contemporary functional art scenes, and highlighted the exhibition called Archaeology Festival at the Tartu Art Museum in 2014 as a positive example of one of the possible present-day models for dealing with beauty.

In connection with a subject that is topical for Tartu and the culturally and artistically aware public throughout Estonia - the preparations for the exposition in the new Estonian National Museum (ERM) - PhD student Margus Tamm was invited to the Autumn School, to represent the large design team ( $3+1$ Architects, Timo Toots, Marko Raat, Margus Tamm and others). His presentation provided a performative rather 
than narrative or visual survey of the problems related to the birth and form of a modern museum's exhibition and the ERM's visions have yet to be revealed in detail.

The second day of the Autumn School was completed by Johannes Saar with a presentation called "A Stylish Man Knows What Good Art Is: The art consumption patterns of the economic elite in Estonia's private media based on the example of the monthly insert called Gentleman in the Äripäev. Excerpts from the text analysis." Art historian Johannes Saar, who is currently a PhD student in Journalism and Media Studies at the University of Tartu and who has worked as an art critic and editor at both the Postimees and Eesti Päevaleht spoke about the methodology and results of his study conducted on the basis of interviews that have appeared for about 10 years in the newspaper's Gentleman insert. Based on the selected text excerpts, he outlined the understanding of hard and soft values blossoming in commercial media that assigns art and artists the role of speaking in romantic, aesthetic and spiritual categories in the spirit of the $19^{\text {th }}$ century in contrast to the rationality of the business world.

The final discussion at the Autumn School developed in an expectedly great challenge to define the current potential and position of beauty, because, in the context of contemporary art, beauty and aestheticism may seem like a kind of taboo - a contrast to meaningful and intellectual art/exhibitions - and the topic is difficult to discuss in a way that transcends local interests and different schools of the art scene. Still the 2014 Autumn School was characterised by interesting presenters, good partners in the form of the University of Tartu Art Museum and the Tartu Art Museum, and a gratifyingly large number of participants (on both days, over 70 attendees were registered). Several of the more distinguished presentations will also be published as articles in the BJAH during 2015. 
Kadi Polli: Autumn School of The University of Tartu's Department of Art History: Art and Beauty

Keywords: Art and Beauty; Beauty in Art; Aesthetics; Male Beauty Ideal

SUMMARY:

The traditional Autumn School of the University of Tartu's Department of History, "Art and Beauty" was conducted on 16 and 17 October 2014 in cooperation with the Tartu University Art Museum and Tartu Art Museum.

The objective of the event, on the one hand, was to introduce the development and modification of the concept of beauty in the history of aesthetics and art; and on the other hand, to examine the problematic relationship that contemporary art and theory has with beauty. Thus, the first day of Autumn School was devoted to the classical traditions of beauty and its peak at the turn of the $19^{\text {th }}$ century, when the University of Tartu was reopened, its ensemble of buildings built and the art museum established. Thereafter, the topic of masculine beauty in the classical art tradition was covered as a separate topic. In addition to the presentations, the interest of the Enlightenment in the human body and antique sculpture was associated with the art project created specially for the Autumn School by Jaanus Samma, a respected and well-known young Estonian artist, who made an "incursion" into the exposition at the University of Tartu Art Museum.

On the second day of the Autumn School, at the Tartu Art Museum, an analysis of the meaning(s) of art in the $20^{\text {th }}$ century and thereafter, today's art, exhibition and media landscape was conducted with the participation of artists, curators and art critics. Whereas, the description of the current potential and position of beauty developed into an expectedly great challenge because, in the context of contemporary art, beauty and aestheticism may seem like a kind of taboo - a contrast to meaningful and intellectual art/exhibitions - and the topic is difficult to discuss.

CV:

Kadi Polli is a lecturer in the Department of Art History at the University of Tartu. She studied art history at the University of Tartu, at the University of Kiel and at the Estonian Academy of Arts. She worked as a curator at the Mikkel Museum, and she curated the painting collection 
at the Kadriorg Art Museum; in 2002-2013 she was Director of both the Mikkel Museum and the Kadriorg Art Museum (branches of the Art Museum of Estonia).

Her main research field is Baltic art and the art scene in the $18^{\text {th }}$ and 19th centuries. She has curated international exhibitions of earlier European art in Estonia, for example, The Swiss Muse. Angelica Kauffmann 1741-1807 (2004) and Dreaming about Mountains. Swiss Landscapes in Baltic Art (2008). She has published scholarly articles and co-authored various catalogues and collections of articles, e.g. Alma Mater Tartuensis. Tartu Ülikool ja tema arhitekt Johann Wilhelm Krause (Alma Mater Tartuensis. The University of Tartu and its Architect Johann Wilhelm Krause, 2003) and Kadriorg. Lossi lugu (Kadriorg. The Story of a Palace, 2010).

Kadi Polli is currently Chair of the Board of the Estonian Society of Art Historians and Curators and a member of the Council of Scientific Research at the Art Museum of Estonia. 